DOI: https://doi.org/10.3126/njdrs.v17i0.34980

\title{
Governance Practices in Nepalese Commercial Banks
}

\author{
Shova Neupane \\ Manager at Global IME Bank, Kirtipur, Kathamndu \\ Email for correspondence: shovaneupane.872@gmail.com
}

\begin{abstract}
This article tries to analyze the existing practices of corporate governance in commercial banks of Nepal. The state of corporate governance can have an important effect on all firms, and good corporate governance of financial firms is essential in fostering financial stability and healthy economic growth. This study found that good corporate governance frameworks help firms and countries improve accountability, more efficiently use capital, and attract quality and long-term investors at lower costs. These, in turn, contribute to a country's competitiveness and thereby its development. The descriptive research design has been adopted for fact-finding and searching adequate information about effect of corporate governance on financial performance. In conclusion, the rapid globalization, international legal deregulation and rapid development in information technology has resulted both opportunity and challenges for the companies. In this context, the success of the organization in global arena is essentially determined by the level of corporate governance that the company is practicing. The efficient and effective corporate governance provides a competitive edge to the company. Management of commercial banks should follow the principles of sound corporate governance to ensure transparency, and accountability through their daily operational process and procedures with clients, and subsequently improve the performance, and enhance investors, shareholders, and stakeholders trust, which contribute to attain the banks goals. Banks require good corporate governance practices.
\end{abstract} Key words: Commercial bank, governance, corporate governance, financial performance

\section{Introduction}

Corporate governance has been emerging as one of the screening tools for both financial and nonfinancial organizations as series of corporate frauds happened in developed and underdeveloped countries. Corporate governance can be defined as a combination of fairness, precision, accountability and sustainability of corporate behavior. Good corporate governance is a key factor to achieve the improved performance of an organization. It is fundamental element to safeguard interest of shareholders. The level of corporate governance can be measured on the dimensions as, financial stakeholder's right and relations, financial transparency, information disclosure, and board structure and process. Hence, corporate governance is the system of rules, practices and processes by which a company is directed and controlled. Corporate governance involves the interest of the different stakeholders in the company. The ultimate objective is to ensure that all financial stakeholders receive their fair share value of the companies earning and assets. In this respect, the world of corporate governance needs place high priority on making its culture, leadership, alignment, systems, and structure more rationalized in terms of their flexibility, complexity and centralization or decentralization. 
The fraud brought negative effect to the corporate performance and stakeholders' interest, and even made some firms go bankrupt (Friedman, 1970, as cited in Chalise, 2014). In addition, the organizational failure to address the governance in many circumstances created the worst condition. For example, as presented in Monem (2001), One-Tel was a major corporate collapse in Australia in 2001. At the time of its collapse, it was the fourth largest telecommunications company in Australia with more than two million customers and operations in eight countries. Numerous scholars and their analyses of quantitative and qualitative data suggest that One-Tel's is a classic case of failed expectations, strategic mistakes, wrong pricing policy, and unbridled growth. The company had serious deficiencies in its corporate governance including in appropriate and in adequate internal control, financial reporting, and audit quality, board's scrutiny of management, poor internal communications, and unjustified executive remunerations. Today's world has seen that organization transparency, financial disclosure, independency, board size, board composition, board committees, board diversity, and fiduciary duties of directors are the cornerstone of good governance practices. These variables are in the main agenda of most meetings and conferences worldwide including the World Bank, International Monetary Fund (IMF) and Organization of Economic Co-operation and Development (OECD) (Inyanga, 2009, as cited in Shunguet al., 2014). Moreover, these institutions consider informed corporate governance standards as critical in helping emerging markets rebuild competitiveness, restore investor confidence, and promote sustainable economic growth (Reddy, 2001; Koufopoulos, 2006; as cited in Inyanga, 2009).

Poor governance is often cited as one of the reason why investors are reluctant or unwilling to invest in companies in certain markets. The corporate governance itself is a risk for investors and in fact it determines the investment decision. The company that is transparent is likely to have better quoted price and market value. In much of the world where corporate governance is not placed important role, companies faces difficulty raising funds. Even in the developed economies where family owned business rules the markets, the companies' funds majority of their investment internally (Mayer, 1990; Pagano-Panetta, \& Zingales, 1995, as cited in Shleifer, \&Vishny, 1997).

The concept of corporate governance has been increasing public interest in recent years due to its plausible importance on the economic health of corporation in general. While financial crisis at culmination, regulators, government and academicians tend to focus on the corporate governance more enthusiastically in order to enhance investors' confidence that would attract more employment of fund in business. Evidence suggests that firms in growing economies are low priced in financial markets because of weak governance (LaPorta, Lopez-de-Silanes, Shleifer \& Visny, 2000). As such, improvements in corporate governance can enhance investor confidence increase these firms' access to capital market (Rajagopalan \& Zhang, 2009). Nowadays, it is not sufficient for the company merely be profitable, it also needs to show good corporate citizenship through environmental awareness, ethical behavior and well corporate governance practices. Generally, corporate governance in nonfinancial sectors require judicious and prudent use of resources of the firm to increase corporate value, increase employee morale, maintenance of market discipline, and stabilize the organization in its end. Corporate governance, thus, rightly, defined as the ways in which suppliers of finance and goods assure themselves that they will receive a fair return on their investment (Shleifer \& Vishny, 1997). If this situation does not exist, outside investor will not be motivated to buy the equity of that firm. This would thus firm 
tend to force to employ internal resources for the firms' profitable investment opportunities. If so then efficiency of the overall performance would likely to suffer and employees and consumers tend to move other firms in the industry.

Jensen and Meckling (1976), Fama and Jensen (1983) revealed that inducement has been given to the managers to confiscate the assets of the firm by endorsing profitable projects, but this is much beneficial to the executives rather than maximizing the value of the firm. Brown and Caylor (2004) asserted that, regulators and government advocates argue that in most of the cases market value becomes overpriced due to poor governance and if this is right the market value of the well governed firm should be relatively undervalued than poor governed firm. Empirical evidences show that greater shareholders rights create higher growth rates, higher profitability and lower cost of capital. Shareholders rights have often been measured after following certain rules and regulation adopted by concern authority (Gompers, Ishii \& Metrick, 2003, Bebchuk, Cohen \& Ferrell, 2009, Bebchuk, 2006). Nepal has recorded a substantial number of bank failures over the last decade. Several banks were placed under the management of a curator; some closed their door whilst many are still facing survival challenges and most writers are relating this to poor corporate governance. Banks are not the only affected part of the economy, even other public and private companies are shaking. There is a yawning gap that exists since none of them covers whether corporate governance has been practices in Nepalese commercial banks.

\section{Objectives}

- To examine corporate governance practices of commercial banks in global context.

- To explain corporate governance practices of commercial banks in Nepalese context.

\section{Methods and Materials}

This study is based on primary data analysis, which mainly deals with qualitative aspects in terms of employee's perceptions of corporate governance practices in Nepalese commercial banks. The following section also reports the result of questionnaire survey conducted among different groups of employees. Questionnaire survey was designed to understand the views of the respondents in relation to their perception on corporate governance elements like board composition, board responsibility, accountability, transparency and disclosure and internal control.In this study, the respondents include employee of 16 commercial banks of Kathmandu valley and 124 questionnaires were collected based on gender and working span of the respondents. The sample size is taken from those banks which are registered in NRB. Therefore, this study consists of 16 commercial banks out of 27 operated till fiscal year 2019.

\section{Major Findings and Discussion: Board Composition}

Board composition is the total number of directors brought from outside the company to sit on the board divided by the board size in each period. Board composition is a debated corporate governance issue since it could influence board deliberations and the capability to control top management decisions and results. The majorities (31.45 percent) respondents agreed that board consists of people from different age brackets, people with different ethnic groups and board includes independent, nonexecutive directors who have no direct relationships with the company, 25.80 percent of people are neutral, 18.55 percent of them strongly agreed and 14.52 percent are strongly disagree and final 9.68 percent are disagree with this statement. 


\section{Board Responsibility}

The important functions of the board include defining the company's purpose, strategizing and drawing up plans to achieving that purpose, appointing the chief executive, monitoring and assessing the performance of the executive team and assessing their own performance. The responsibility of the board of directors is to ensure 'good' corporate governance. The following figure 2 shows the responses associated with board responsibility in Nepalese commercial banks. The majorities (41.94 percent) of the respondents agreed that board is responsible for developing mission, vision and strategic objectives of the banks, they decides the 'corporate governance policy' of banks and all board members participate in the board meetings, 20.97 percent of people are neutral, 17.75 percent of them strongly agreed, 11.3 percent are disagree, 8.04 percent are strongly disagree with this statement.

\section{Accountability}

The corporate governance framework should ensure the strategic guidance of the company, the effective monitoring of management by the board, and the board's accountability to the company and the shareholders. Ensuring the integrity of the essential reporting and monitoring systems will require the board to set and enforce clear lines of responsibility and accountability throughout the organization. The accountability of the board and the board as a whole should be clear. The majorities (59.9 percent) of the respondents agreed board ensures that satisfactory communication takes place with shareholders and is based on a mutual understanding of needs, objectives and concerns, board works as a cooperative and reliable team in the interest of all shareholders and other stakeholders, directors maintain good standards of business conduct integrity, ethical behavior, operate with due care and diligence and at all times act honestly and openly and board ensures that employees are fairly treated and appropriately remunerated, 29.2 percent of people are neutral, 11.3 percent of them strongly agreed and 5.6 percent are disagree and finally 4 percent are strongly disagree with this statement.

\section{Transparency and Disclosure}

Transparency and disclosure are set of parameters which covers various aspects of corporate practices including a firm's openness about financial and operational information, its ownership structure, and shareholders rights under the company's governing legal documents and the capabilities of the individual board members and management. They are key aspect of the modern corporative governance mechanism and is important element affecting how attractive a firm appears to potential investors. The following figure 4 shows the responses associated with transparency and disclosure practices in context of Nepalese commercial banks. The majorities ( 57.5 percent) of the respondents agreed that financial reports of the banks are accessible though internet and websites of the company, bank publishes the company's strategic objectives, banks disclose remuneration for managers and board members and the shares owned by board are clearly elaborated and listed by the company, 22.6 percent of them strongly agreed, 12 percent of people are neutral, 4.7 percent are disagree and 3.2 percent are strongly disagree with this statement. 


\section{Internal Control Mechanism}

The internal control system is responsible for all controlling structures and processes and therefore supports the bank through its operations. A well-functioning internal control system is a fundamental management element that seeks to ensure that the bank's goal may be achieved. The majorities (55.6 percent) of the respondents agreed that the bank tracks the changes in the ownership structures on a regular basis, rights and responsibilities of shareholders are effectively managed and communicated, awards and bonuses given to managers depend on the performance of the bank and corporate governance policies of banks are relevant and composed after considered of all stakeholders, 25 percent of people are neutral, 11.4 percent of them strongly agreed, 4.8 percent are strongly disagree and 3.2 percent are disagree with this statement.

\section{Bank Performance}

Corporate governance is considered an important determinant of bank performance in many literatures. Good corporate governance practices affect firm performance. Therefore, firms that practice good corporate governance bring about better management resulting in monitored transparency and accountability and prudent allocation of company's resources, which enhances the financial performance resulting in a higher ROE and ROA, which in turn will result in higher share prices. The majorities (52 percent) of the respondents strongly agreed that bank performance is good and satisfactory 36.7 percent of them agreed, 7.3 percent are neutral and 4 percent are disagree with this statement.

\section{Conclusion}

This study comes to the conclusion that corporate governance is becoming an issue of global significance. The rapid globalization, international legal deregulation and rapid development in information technology has resulted both opportunity and challenges for the companies. In this context, the success of the organization in global arena is essentially determined by the level of corporate governance that the company is practicing. The efficient and effective corporate governance provides a competitive edge to the company. Besides competitive edge, the company assessment on risk of corporate governance brings company to have stronger access to financial and capital market globally. Most importantly today's global financial world is dominated by institutional investors and in such condition the effective assessment of corporate governance results better financial doors and source of capital.

Likewise, corporate governance practices are positively correleated with bank performance even in Nepalese context. The Nepalese commercial banks are successfully practicing corporate governance activities such as representative boar members, accountable and responsible banbking services, transparent finacuial and operational information, effective internal control mechanism and satoisfactory performance. Hence, Nepal Rastra Bank should encourage banks to implement good corporate governance practices through enacting rules and regulations and monitoring mechanism for making shareholders and other stakeholders more accountable and responsible. 


\section{References}

Chalise, M. (2014). Impact of corporate social responsibility on corporate governance and reputation in Nepalese commercial banks. The Journal of Development and Administrative Studies, 22(12), 27-36.

Inyang, B. (2009). Nurturing corporate governance system: The emerging trends in Nigeria. Journal of Business Systems, Governance and Ethics, 4(1), 2.

Monem, R. (2001). The one-tel collapse: Lesson for corporate governance. Retrieved fromhttp:// www98.griffith.edu.au/dspace/bitstream/handle/10072/42673/74746_1.pdf.

Shleifer, A., \& Vishny, R. W. (1997). A survey of corporate governance. The Journal of Finance, 52(2),737-783. Retrieved from http://down.cenet.org.cn/upfile/45/200815123912106.pdf.

Shungu, P., Ngirande, H., \& Ndlovu, G. (2014). Impact of corporate governance on the performance of commercial banks in Zimbabwe. Mediterranean Journal of Social Sciences, 5(15), 93-105. 